\title{
Supermax i Silkeborg
}

\author{
En rapport anmeldt af Henrik Tvermoes
}

\section{Da Supermax flyttede ind på Biblioteket - Historien om, hvordan Silkeborg Bibliotek inddaterede materialebestanden på 14 dage / Kurt Balle Jensen .. et al. - Silkeborg : Silke- borg Biblioteks Forlag, 1990. - 65 sider + bilag. - (Silkeborg Biblioteks Skriftserie, Bind 7) - Pris ikke opgivet.}

I foråret 1990 holdt EDB-teknologien for alvor sit indtog på Silkeborg Bibliotek. Supermax, som i andre sammenhænge kunne være navnet på enten en tegneseriekarikatur af James Bond eller i OLsammenhæng navnet på en dansk hest, blev en del af hverdagen. Men hvem er egentlig Supermax?

Rapporten som er blevet til i et samarbejde mellem bibliotekets PR-udvalg og journalist Kurt Balle Jensen, er et forsøg på at besvare dette spørgsmål og videreformidle nogle af de erfaringer som man gjorde, da biblioteket som det første i Danmark gjorde brug af kampagnemetoden i forbindelse med inddatering af materialebestanden.
I dette perspektiv har rapporten virkelig noget at give. Stilen er uortodoks og direkte (det er en "uortodoks rapport om et uortodokst forår", side 2), og budskabet går lige ind. Det handler om vigtigheden $\mathrm{i}$, at alle deltager på lige vilkår. I Silkeborg fik det sociale fælleskab en afgørende betydning for inddateringsprocessen. Alle var med, og alle fik den samme undervisning. I starten foregik undervisning i plenum, og blev varetaget af en ansat i Dansk Data Elektronik, men efterhånden gik man over til, at medlemmer af personalet, som havde modtaget en grundig undervisning, underviste kollegerne $\mathrm{i}$ grupper på en 6-8 personer. Dette betød, "at alle var trygge ved det, der skulle ske" (side 19).

Ligeledes pointerer rapporten vigtigheden af det arbejde, som PR-udvalget gjorde i forbindelse med at gøre lånerne opmærksomme på, hvad det var der skulle ske. Man havde tilrettelagt en såkaldt informationskampagne, og gjorde her bl.a. brug af de forskellige medier som f.eks. lokal-radioen og de lokale aviser. 
Men det er også historien om computeren, der sov længe, om det at sidde med adgang til flere hundrede tusinde data og så finde det, man sidder med $\mathrm{i}$ hånden, om bladresystemer og om øl. Ligesom det er historien om veteranernes endeligt, om brug af sygesikringskort til notering via EDB, om tyverisikring og om sikkerhed.

Rapportens formål er således en afmystificering af kampagnemetoden og det optimistiske budskab er: Kom så i gang. Dette er i og for sig reelt nok - og også nødvendigt.

Sagen er bare, at der bag den positive facade skjuler sig nogle problemer. I et lidt bredere perspektiv har EDB-indførelsen i Silkeborg nemlig også betydet, at der til dels er sket en opbygning af hierarkier blandt de ansatte. Det opfattes af flere sådan at de, der $\mathrm{i}$ deres arbejde beskæftiger sig mest med EDB, har den højeste status. Og i forlængelse heraf giver en del ansatte på biblioteket udtryk for, at EDB-indførelsen er gået for meget ud over bibliotekets kulturformidlende funktion, noget som de ser som et stort problem. Mens andre peger på informationsformidling som den eneste vej frem. I forholdet til lånerne er brugen af EDB heller ikke problemfri. Man har mistet taget i nogle grupper af lånere - specielt de ældre - idet annoncerede kurser $i$ oplæring $i$ brug af systemet har været en fiasko. Endvidere kan nævnes, at hverdagen for hovedparten af de ansatte føles mere stresset. Baggrunden for dette er de lange ventetider, men nok så meget de øgede krav, som lånerne stiller til bibliotekaren. Fordi lånerne, når de ser en skærm, har en forventning om, at systemet har svaret på netop deres problem. Dette betyder to ting: For det første foregår låneservicen udelukkende på lånernes præmisser, og for det andet giver flere bibliotekarer udtryk for, at det er et problem for dem, at det nemt kan se ud som om, at de bare skal trykke på knappen, så laver maskinen arbejdet. Flere føler at deres status og identitet berøres negativt af denne forestilling.

Konklusionen på læsningen af rapporten må således være, at den helt klart har en funktion, nemlig udbredelse af erfaringer $i$ forbindelse med inddatering, som kan blive til nytte og gavn for biblioteker, der i de kommende år vil komme til at stå i samme situation. Og det kan i denne sammenhæng tilføjes, at mange af de erfaringer, som man har gjort i Silkeborg, er af generel karakter.

Specielt m.h.t. stilen kan rapporten dog nemt komme til at virke overfladisk. Rapporten satter ikke ligefrem bibliotekets/personalets lys under en skæppe, og man får lidt på fornemmelsen, at i Silkeborg kan de bare det der. Man savner en redegørelse for hvad der ligger bag, at man er kommet så langt. F.eks. hvad angår personalets forventninger til EDB'en. Problemet i denne måde at fremstille tingene på er, at den kan virke lidt ensidig og forenklet. $\mathrm{Og}$ er der noget, som indførelse af EDB ikke er, så er det enkelt. Det er derimod en uhyre spændende proces med mange opmuntringer og problemer - også i Silkeborg. 